\title{
Using Online Computer Games in the ELT Classroom: A Case Study
}

\author{
Ioanna Vasileiadou ${ }^{1} \&$ Zafiri Makrina ${ }^{2}$ \\ ${ }^{1} 7$ th Primary School of Orestiada, Hellenic Open University, Greece \\ ${ }^{2}$ School of Foreign Languages, Aristotle University of Thessaloniki, Greece \\ Corresponding: Ioanna Vasileiadou, 7th Primary School of Orestiada, Ethnomartyron 5A, 68200, Orestiada. Tel: \\ 30-6936159353. E-mail: ioanna_va@yahoo.gr
}

Zafiri Makrina, School of Foreign Languages, Aristotle University of Thessaloniki, Greece, Tel: 31-693-411-8194. E-mail: m_nzafiri@yahoo.gr

Received: August 3, $2017 \quad$ Accepted: November 6, $2017 \quad$ Online Published: November 8, 2017
doi: 10.5539/elt.v10n12p134 $\quad$ URL: http://doi.org/10.5539/elt.v10n12p134

\begin{abstract}
The purpose of this research was to investigate the effectiveness of computer games in learning English as a foreign language and the extent to which they increase motivation in young students. More particularly, this research investigated the validity of the hypothesis that computer games are a particularly motivating means for young students to learn English vocabulary effectively in comparison to other approaches suggested by the Greek National Curriculum. The grade, in which this research was conducted, was the 4th grade of Primary school as it is a borderline grade in which greater demands are imposed on the students of this age group and language level regarding, mainly, their reading and writing skills as in this class, for the first time, it is explicitly stated by the national curriculum that literacy is one of the three basic axons upon which English language learning should be developed. All in all, the results of this research shed light on the effects which new technologies have on language learning as well as their ability to motivate students to learn English. The results of this research will also be used as a basis upon which specific suggestions for the practical implementation of computer games in the everyday classroom can be made.
\end{abstract}

Keywords: young students, online games, technology, case study, action research, semi-structured interviews

\section{Introduction}

The importance of vocabulary in foreign language learning cannot be emphasised enough (Boonkongsaen, 2012; Laufer, 1997). No matter how significant the role of grammar or syntax is, no matter how much emphasis is placed on teaching skills, it is eventually words or chunks of words that will convey the meaning of an intended utterance and it is eventually words that one needs to communicate from the simplest of ideas to the most complicated ones (McCarthy, 1990). Learning vocabulary, therefore, is the "sine qua non" (Chambers, 1999, p. 122) of language learning. Without it there is little success for effective communication (Vermeer, 1992) as it is upon words that the structure of language is built and it is words that constitute the raw material for the creation of sentences (Ross \& Jan, 2007).

Learning new vocabulary, however, or expanding one's knowledge on the features of already acquired vocabulary, is a rather demanding task (Boonkongsaen, 2012) as there are several factors affecting vocabulary learning in a foreign language, which can be divided into two broad categories; intralexical and extralexical (Takac, 2008). Intralexical factors concern the "intrinsic properties of words that might affect its learnability" (Laufer, 1990, p. 141), which can include their pronunciation, orthography, length, morphology, synformy, level of abstractness, specificity and register restrictions, as well as idiomaticity and multiplicity of meaning (Laufer, 1990). Not all students, therefore, are affected in the same way or to the same degree by these intralexical factors and which words will eventually be found difficult to learn, depends, each time, on the students' linguistic background, more, rather than on the features of the words as such (Ringboom, 1985; Swan, 1997).

However, despite the significant intralexical factors which can influence vocabulary learning and apart from each student's linguistic background, there are extralexical factors that can either accelerate or decelerate language learning (Ellis, 1994). These extralexical factors are comprised of personal factors, such as students' previous language experience, their motivation, their attitudes and beliefs about language learning, as well as of social factors regarding the student's level, the course type which they attend and even their learning 
environment (Boonkongsean, 2012). In fact, these extralexical factors are so significant that they overshadow the intralexical ones, as no matter how easy or simple a word might be, phonologically or morphologically, when a student is demotivated or unwilling to learn it, then that word will simply not be remembered (Osguthorpe \& Osguthorpe, 2009).

In the Greek Primary school, however, students are exposed to, and taught, English vocabulary mainly through books which are set for this particular grade by the Greek Ministry of Education and Religious Affairs. The main focus of these books is to promote the principles of crosscurricularity, multilingualism and multiculturalism, which are endorsed by the Greek Curriculum for Foreign Languages and to develop the students' skills in English as a foreign language through crosscurricular projects and activities. The necessary vocabulary that students need, so as to carry out these activities successfully, receives secondary attention and students are neither taught not trained in vocabulary learning strategies, which could help them remember new words in an easier manner (Cameron, 2001). New words are presented through drilling activities (Mpratsioli \& Diamantidou, 2009) and are treated as a means with which the four skills can be developed, as was typical of coursebooks used about two decades earlier (Coady \& Huckin, 1997; Meara, 1980).

In an effort to alleviate some of the burden vocabulary poses on students, the researchers who are also the teachers decided to implement the differentiated instruction principles in a particular class of Primary school and attempted to find out whether the students of that specific class would be assisted in their effort to acquire English vocabulary.

The purpose of this research is to investigate the hypothesis that computer games can assist young students in learning their vocabulary effectively. To this purpose, two research questions were posed:

(a) Do computer games make vocabulary learning in English more enjoyable?

(b) Are computer games effective in learning vocabulary in English?

\section{Literature Review}

Regarding the use of computer games in assisting students to learn and to remember new vocabulary in the English language, there have been several studies conducted (Gee, 2003). Ashraf, Motlagh, \& Salami (2014) studied 24 students who were at a low-intermediate level for over a period of 15 weeks. Students were randomly separated into an experimental and a control group. The experimental group was allowed to practice vocabulary with the use of computer games while the control group did other vocabulary related activities. Their findings indicated that the experimental group outperformed the control group and proved that computer games were "effective in vocabulary acquisition" (Ashraf et al., 2014, p. 290).

In addition, Calvo-Ferrer (2017) researched the effect of computer games in vocabulary acquisition. His experimental group was exposed to new vocabulary through computer games while the control group practiced vocabulary by doing other activities (such as vocabulary exercises in their course books). After analyzing the results of the pre-test and the post-test, which he had given to both groups, he found that students who were allowed to use computer games scored significantly better in the short run than the ones who used other means of practicing vocabulary. What is more, students of the experimental group also claimed that computer games were appealing and that they assisted them in developing their vocabulary skills.

Segers and Verhoeven (2003) studied the effects of intensive vocabulary training through computer games in kindergarten in the Netherlands. A hundred and sixty-four students participated in their study, which lasted 15 weeks. During this time, 67 students, who belonged to the experimental group, played computer games for 15 minutes twice a week while 97 children, who belonged to the control group, followed the regular curriculum. Their results indicated that computer games had a positive effect on the children's vocabulary.

Finally, similar findings were also reported by Saffarian and Gorjian (2012) who investigated the role of computer games in EFL. Their research involved 418 EFL teachers and learners who were divided into two groups. One group used computer games in their lesson while the other followed the school's regular lessons. The data, which was statistically analyzed, showed a significant difference in the performance of the experimental group compared to that of the control group.

Furthermore, Sundqvist and Sylvèn (2014) studied the extent to which young learners in Sweden were involved in language related digital games as well as the relationship between playing digital games and learners' motivation to learn English. Their study involved 76 English language learners in the $4^{\text {th }}$ grade of primary school. According to the research results, obtained, most of the young learners, particularly the male learners, were actively involved in language learning activities while all learners' motivation to learn English seemed to augment. 
On the other hand, Bytheway (2014) studied the effects of Massively Multiplayer Online Role-playing Games (MMORPGs) on learners' use of vocabulary learning strategies in a case study which involved six experienced game players. The results of her research have revealed that MMORPGs are rich and meaningful vocabulary learning contexts, which advance the players' vocabulary and affect their vocabulary learning strategies.

In Denmark, Jensen (2017) studied the effects of extramural English in 107 children aged 8 and 10 years of age who had little or no prior English knowledge. The children were asked to keep diaries of the time they spent daily on various extramural activities and at the end of the research they were given the Peabody Picture Vocabulary Test (PPVT-4). The study revealed that children engaged mostly in gaming, watching TV and in listening to music and it was concluded that gaming, in particular, is significantly related to higher vocabulary scores in foreign language, mostly for boys.

Finally, Yudintseva (2015) in a synthesis of 17 quantitative, qualitative and mixed method studies revealed that learning which is enhanced by computer games not only provides learners with a set of valuable strategies when learning a foreign language but also an opportunity for learners to use vocabulary in authentic contexts. Despite the fact that the studies, which she presents, do not come to a conclusion regarding which particular video game strategies are more beneficial in foreign language learning, they all nevertheless conclude that, generally, foreign language vocabulary is enhanced when learners engage in playing video games.

\section{Methodology}

With a view to test this research hypothesis, the researchers, who are also the teachers, conducted a case study which is also an action research since it observes a certain phenomenon within a specific case and collects information regarding how this phenomenon develops within this case during a specific period of time (Swanborn, 2010) with a view to allow professionals to gain a deeper understanding of their practices, to evaluate them and to improve them (Frost, 2002; Hopkins, 2002).

In addition, this research also used an Independent Measures (McLeod, 2007), Pre-test-Post-test (Moorhead, 2006) experimental design so that the effectiveness of computer games as a method of teaching English vocabulary in comparison to other methods would be investigated. To this purpose, the teachers used two groups of students of the same grade but of different Primary schools, which would constitute the experimental group and the control group respectively. The classification of the two classes into an experimental and a control group was based on practical reasons; The computer laboratory in the $7^{\text {th }}$ Primary school of Orestiada is well-equipped with relatively new computers while the computers in the $3^{\text {rd }}$ Primary school laboratory are obsolete and neither their RAM nor their screen analysis are sufficient for new computer games to work appropriately. As a result, the students of the $7^{\text {th }}$ Primary school were selected as the experimental group, since this group would have to work on computers, while the students of the $3^{\text {rd }}$ Primary school were selected as the control group. The former was offered the opportunity to practice vocabulary by playing computer games while the latter practiced the typical vocabulary tasks suggested by the school's curriculum. In this experimental design, therefore, the independent variable, which would be applied only to the experimental group (Baker \& Milivojevich, 2016), was the use of computer games as a means of learning and practicing English vocabulary.

\subsection{Reasons for Selecting Computer Games}

The selection of computer games, compared to other means of teaching young students, was not decided upon arbitrarily by the researchers who were also the teachers. Quite the contrary, in accordance with the fundamental principle of differentiated instruction which supports that students should be given the liberty to choose the process they consider most beneficial for their learning progress (Tomlinson, 2001), before deciding on computer games, the researchers (who were also the teachers) first investigated their students' preferences regarding vocabulary teaching. These ways included computer games, project work, songs, role-play drama, classroom games, the use of the Internet, European project work programmes (Teachers4Europe and eTwinning) and vocabulary- list(s) learning.

The tool, which was used to investigate the particular students' preferences and needs, so that the lesson could be adjusted to them, was a semi-structured interview, which was conducted in the students' classroom after their lessons had finished or during long breaks. Each interview lasted about 3-6 minutes during which students were allowed to express their opinions regarding the teaching methods that were used in the lessons as well as the extent to which the methods used seemed motivating and/or beneficial in their effort to learn English. During the semi-structured interview, the researchers, who were also the teachers, asked students what they thought of the different means through which they were taught vocabulary. In particular, they asked students what they thought about each one of the ways which were applied, by the researchers (who were also the teachers) during the lessons, to learn vocabulary. The first question aimed at investigating the extent to which each means of learning 
vocabulary was enjoyable for the students and the reasons why they believed that. The second question intended to investigate the extent to which the students believed that each way of learning vocabulary helped them learn words more easily. In the last question, students were asked to choose one way which, in their opinion, was the most enjoyable and effective of all and which could be applied as a means of differentiating instruction in their lessons.

After a meticulous analysis of the semi-structured interview results, it became evident that computer games were regarded not only as the most efficient method for students to boost their vocabulary but also as the most engaging. According to the results, of all the methods that their teachers used to help their students learn vocabulary in the classroom, $57 \%$ regarded computer games as the most enjoyable (see Figure 1), $40 \%$ as the most beneficial (see Figure 2) and $61 \%$ maintained that it was the tool they would prefer to use the most during the lesson (see Figure 3).

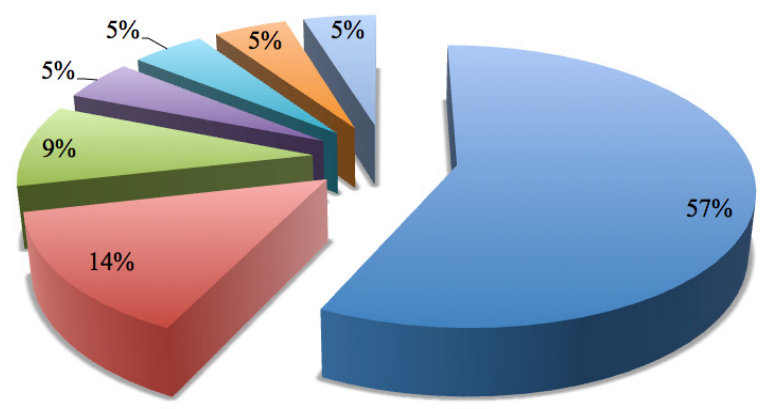

\author{
- Playing online computer games \\ - Playing guessing games in the classroom \\ - Using flashcards \\ - Singing \\ - Reading \\ Doing exercises in the books \\ None in particular
}

Figure 1. Students' preferences regarding different ways of learning vocabulary

These findings are in agreement with the findings of similar research which was conducted, in the field, and in which learners enjoyed using a computer more and also claimed that they benefited more from computer games. More particularly Letchumanan and Bee Hoon (2012), examined the extent to which computer games were the students' preferred way of learning vocabulary. In their research $90 \%$ of the students, who were interviewed, stated that computer games were the most preferred means of learning vocabulary, as computer games were not only enjoyable but they also helped them remember words better than any other means of practicing vocabulary. These findings are also in line with Yip and Kwan (2006) who investigated 100 students in a quasi-experimental study regarding the effect computer games had on the students' vocabulary range and motivation to learn it. The results of this study confirmed that computer games were the students' preferred way of learning words compared to all other activity based lessons.

According to Prensky (2001), the fact that young learners prefer using computer games in their lesson should be expected. Young leaners are "digital natives" (Prensky, 2001, p. 1). Born in the era of technology, young learners take the use of computers and the Internet for granted, and playing computer games comes naturally to them. It is no wonder, therefore, that the new generation of students shows a clear preference to anything and everything which is connected to technology. Besides, the students of the current research often pointed out to the researchers (who were also their teachers), during the semi-structured interviews, that they simply like everything which relates to computers and that this was the reason they preferred computer games to all other activities which were done in the classroom. 


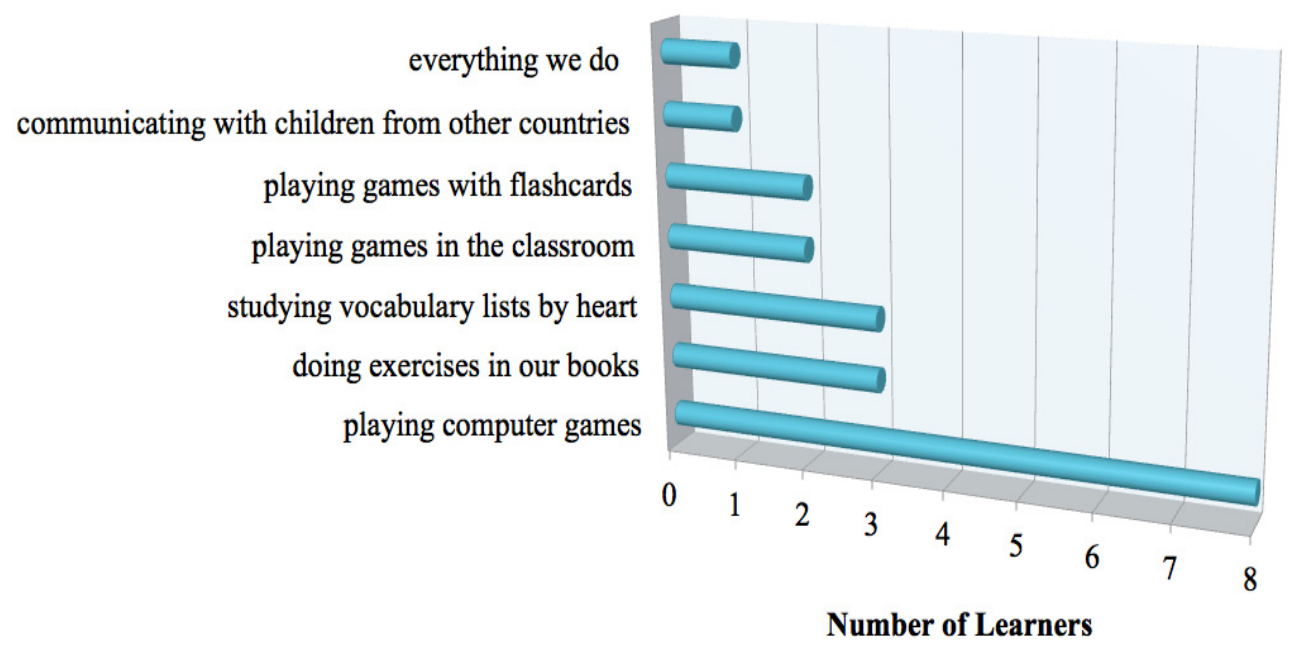

Figure 2. Students' beliefs regarding the activities they find most beneficial in remembering vocabulary

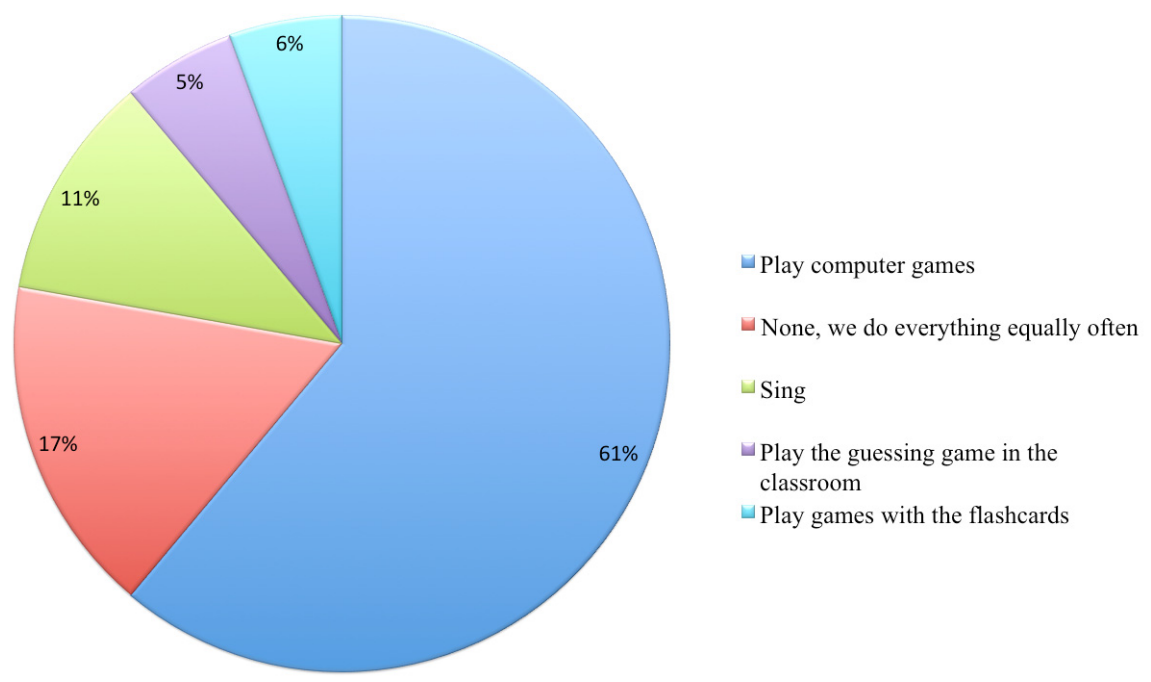

Figure 3. Students' preferred activity

However, despite the students' stance regarding the way they would rather learn vocabulary in their lessons (since $61 \%$ of them chose to be taught vocabulary through computer games, see Figure 3), it was also considered pivotal, on behalf of the researchers (who were also the teachers), to test whether the students' preference would actually be effective in practice. This was the reason why the effectiveness of the use of computer games in teaching vocabulary was examined in this research.

\subsection{Participants}

The students of the experimental group attended the $4^{\text {th }}$ grade of the $7^{\text {th }}$ Primary school of Orestiada, a small school on the outskirts of the town with 115 pupils in total. The particular class which participated in the research is a class of 19 students, 8 boys and 11 girls, in the $4^{\text {th }}$ grade of Primary school. Apart from one boy who had to repeat a class at a younger age and who was, therefore, a year older, all the students in this class were aged nine. Five of the children were of ROMA origin and Turkish was their mother tongue. The ROMA children faced many difficulties in speaking and writing the Greek language and three of them rarely attended lessons.

On the other hand, the control group was a class of 14 students in the $4^{\text {th }}$ grade who attended the $3^{\text {rd }}$ Primary school in another part of the same town, which consisted of 14 students, 6 boys and 8 girls, all aged ten, apart from a girl who had to repeat the first year of Primary School and was eleven. Ten students in the control group, four girls and six boys, were Greek while the other four were girls of ROMA origin. Three of the ROMA girls spoke Turkish as their mother tongue and one Bulgarian. Concerning the English lesson, none of the ROMA 
girls were able to read or write the English alphabet despite the fact that they had been learning English since the $1^{\text {st }}$ grade of Primary school and none of them showed particular interest in the lesson.

\subsection{Instruments}

The tool which was used to collect data in this research was the semi-structured interview, which was conducted to the students of the experimental group both at the beginning and at the end of the research. The reason why the semi-structured interview was chosen, as the most appropriate tool for this particular research, was because it offered a combination of structure, immediacy and flexibility to the research (Reason \& Bradbury, 2006).

\subsection{The Adapted Content}

The content of the book that was adapted for the purposes of the research was the English for the $4^{\text {th }}$ Grade Student's Book (Mpratsioli \& Diamantidou, 2011a) and Workbook (Mpratsoli \& Diamantidou, 2011b). In particular, the vocabulary from the first two units, of the aforementioned books, was thematically re-organised and was presented to the students of both the experimental and the control group with a variety of teaching methods appropriate for young students (songs, drama, story telling, use of the internet, games). What was fundamentally different, however, was the way each group practiced the vocabulary it was exposed to. The control group did not deviate from the coursebook's material, whereas the experimental group was offered the opportunity to practice vocabulary by a method of its choice, that is, by playing relevant computer games.

\subsection{Procedure}

At the beginning of the research the students of both the experimental and the control group were given a pre-test so that their level of English would be determined. The pre-test included material students had been taught in the previous grade and were expected to have mastered by the time they started the $4^{\text {th }}$ grade. Given that the focus of the research was vocabulary, students were tested only on specific vocabulary items, which should already have been acquired by students of this age group and language level so that their transition from the $3^{\text {rd }}$ grade to the $4^{\text {th }}$ grade would be smooth and unobstructed. The results of the pre-test revealed that, comparatively, there was no significant difference in the performance of the two groups of students (see Figure 4 and Figure 5) and that both the experimental and the control group would start the $4^{\text {th }}$ grade with the same level of English.

The research was based on the vocabulary presented in the first two Units of English for the $4^{\text {th }}$ grade Student's book (Mpratsioli \& Diamantidou, 2011a) and Workbook (Mpratsioli \& Diamantidou, 2011b). Lessons were organised in groups of two with the first lesson always being a presentation of new vocabulary through focus on a particular skill (listening, speaking, writing, reading) while the second lesson intended to offer students the opportunity to practice and eventually learn the newly presented vocabulary. For students of the control group, however, the practice of new vocabulary was limited only to the practice offered by the Student's book and Workbook tasks. On the other hand, the students of the experimental group were given the opportunity to practice the same vocabulary by playing relevant computer games, as, according to the results acquired by the semi-structured interview, conducted at the beginning of the school year, this was the method that they considered the most enjoyable and effective.

The computer games were chosen from a list of free online game sites based on their relevance with the vocabulary presented in the preceding lesson and students were given the opportunity to choose a variety of games which related to this vocabulary, according to their likes, interests and abilities. Given that the number of computers in the school's computer laboratory was less than the number of students who attended the class, students were seated in groups of three and took turns when playing the specific computer games. The first game to be played, by all groups, was usually chosen by their teachers (who were also the researchers) so that students would not deviate from the target vocabulary, which the teachers wanted them to practise, so that the learning goals of each lesson would be achieved, but after that, each group was given the choice to either play the same game again, continue to a relevant game or abandon the initial game for a more difficult or an easier one.

After 24 weeks, students of both the experimental and the control groups were given a post-test. The tasks in the post-test of both groups were identical as was the time which was allotted to each student to complete them. The only difference was that the experimental group completed the tasks online by playing specific computer games, which were selected for this purpose, while the control group completed exactly the same tasks after they had been printed out on paper. In order for the teachers to be able to assess their students' achievement during the online test, the students were separated into groups of four and each group took the test, in turns, while the teachers were monitoring and recording their responses. The first response each student gave was marked as either right or wrong and in the end a total was calculated and a final mark was given to each student. The results of the post-tests were used to evaluate the extent to which the teaching methods implemented had been effective 
to either class of students so that conclusions regarding the effectiveness of computer games on teaching vocabulary could be drawn.

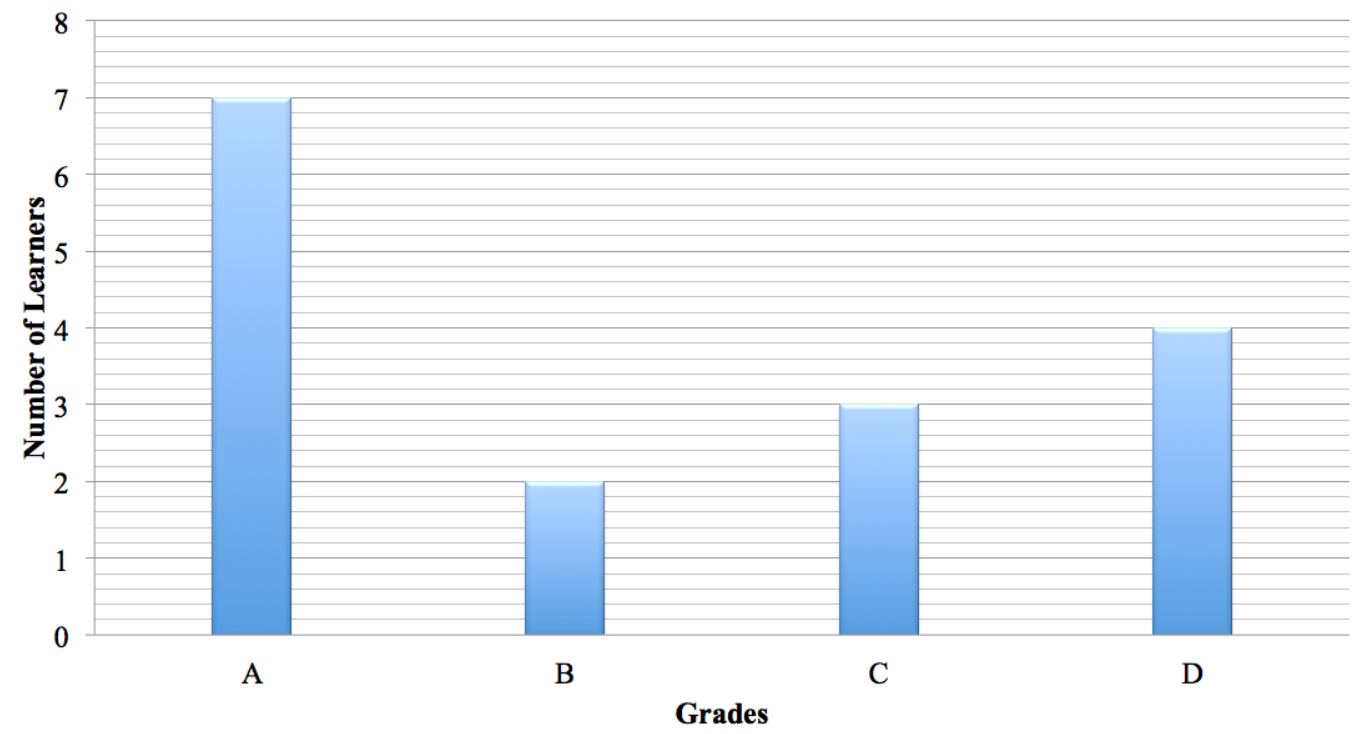

Figure 4. Control group pre-test results

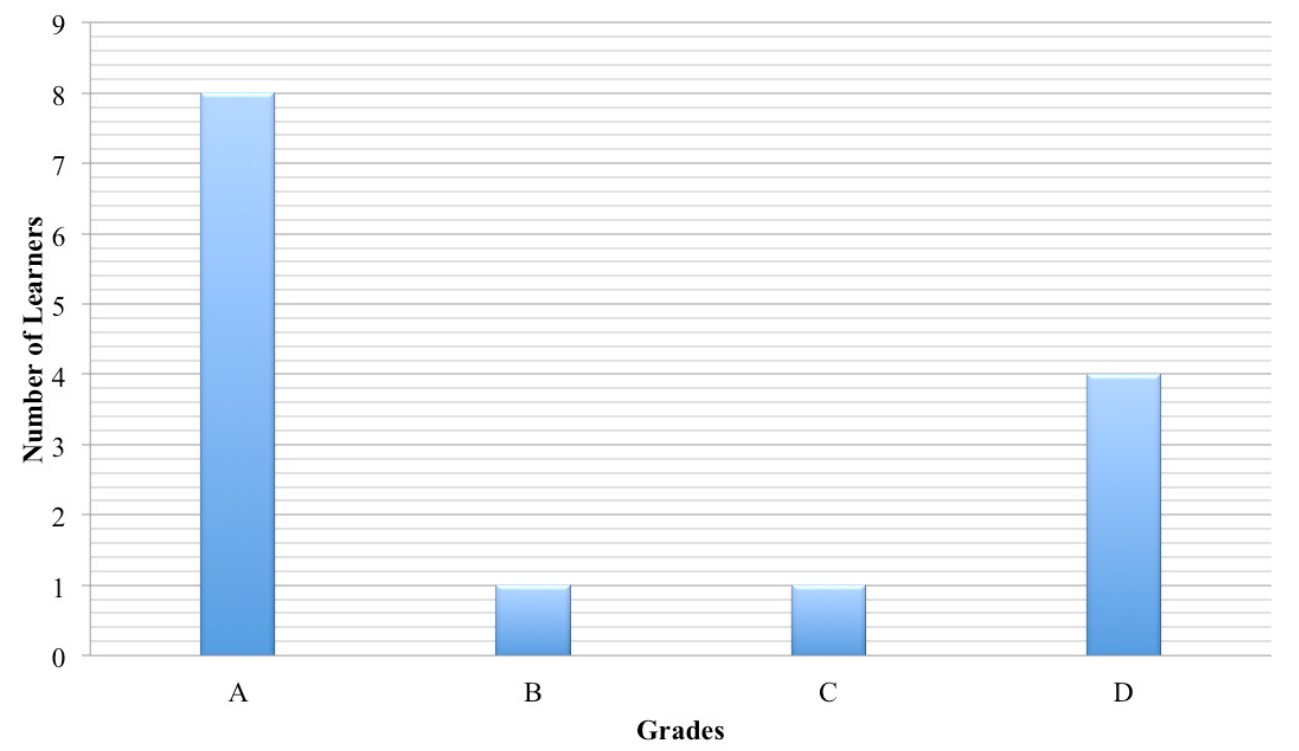

Figure 5. Experimental group pre-test results

\section{Results}

The data of this particular research was collected from two sources. The first was the post-test which was given to the students of both the experimental and the control group to objectively evaluate the extent to which they had acquired the target vocabulary while the second was a semi-structured interview conducted to the students of the experimental group, with which the researchers, who were also the teachers, investigated the subjective opinion of the students regarding the effectiveness of computer games.

\subsection{Pre-test and Post-Test Results}

The results of the post-test revealed that students of both the experimental and the control groups who had written well in the pre-test wrote equally well in the post-test, scoring more than $75 \%$ in both tests (see column A in Figure 4; Figure 5; Figure 6 and 7). 


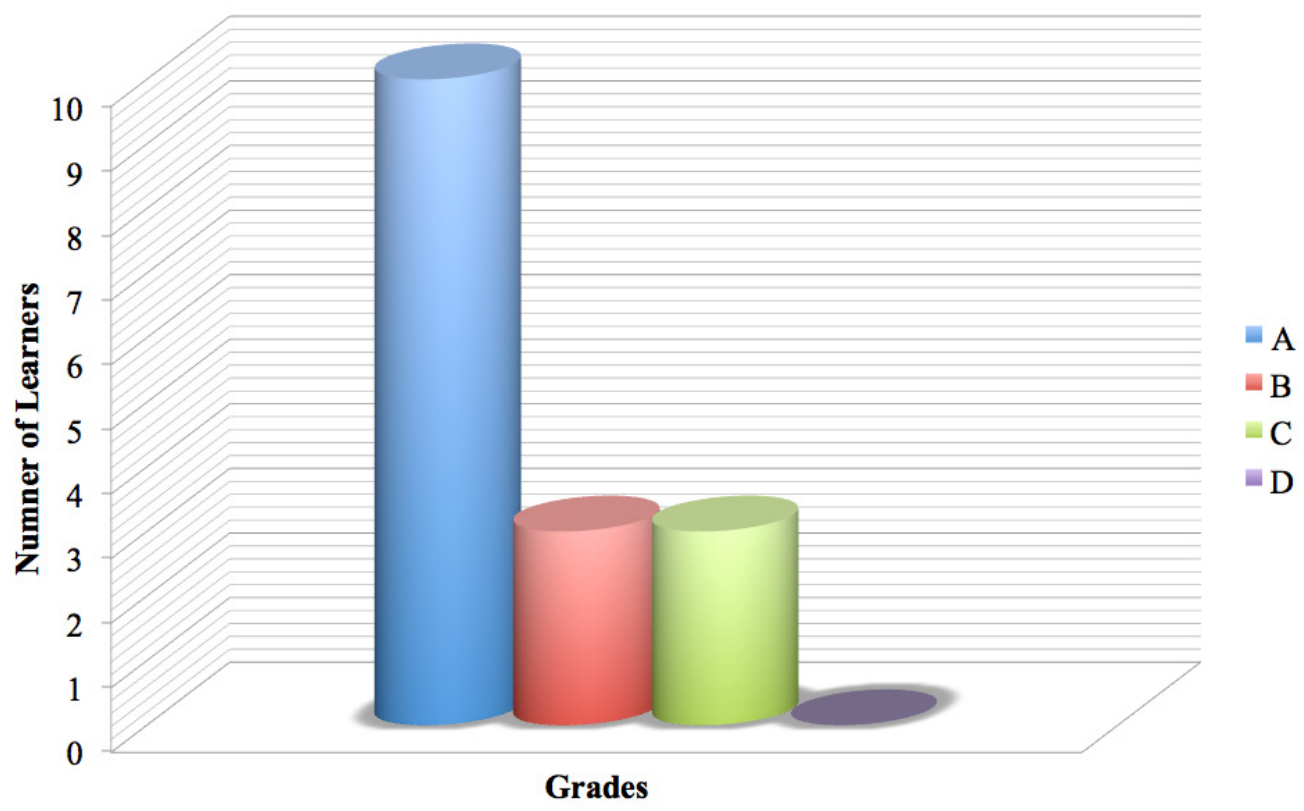

Figure 6. Experimental group post-test results

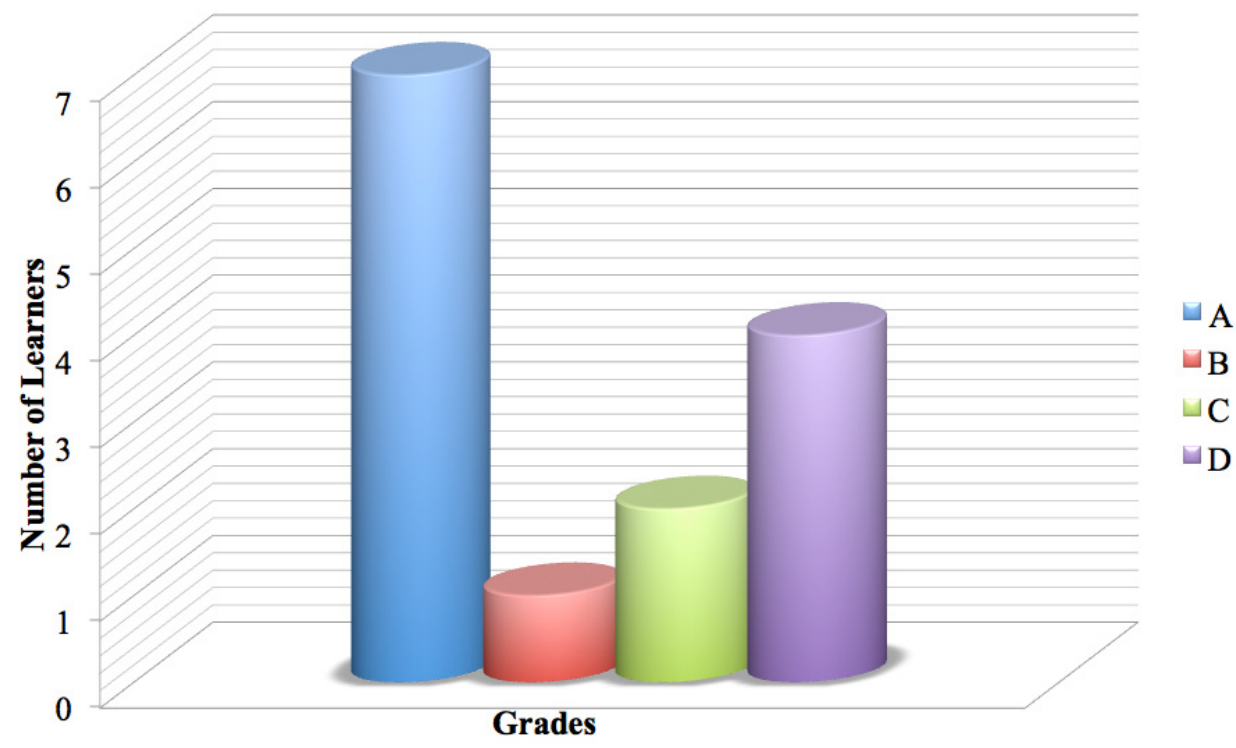

Figure 7. Control group post-test results

The fundamental difference between the control and the experimental group was in the achievement of the students who in the pre-test had scored the lowest. In the pre-test, $28.5 \%$ of the students of the control group, that is 4 out of 14 students scored below 25\% (see column D in Figure 4) and this percentage remained unaltered in the post-test (see Figure 7). In the experimental group, however, the results differed; While in the pre-test $25 \%$ of the students scored below 25\% (see column D in Figure 5), in the post-test their scores were significantly higher with students of this group scoring as much as $56.8 \%$, while none scored below $25 \%$ (see columns C \& D in Figure 6).

Similar findings were also reported by Yip and Kwan (2006) who investigated the usefulness of computer games in learning vocabulary. In their study 100 students were under scrutiny for a period of nine weeks. The students were divided into an experimental and a control group and a vocabulary pre- and post-test was given to them at 
the beginning and at the end of the research period. Their findings were in accordance with the findings of this research and showed that the experimental group statistically outperformed the control group in the post-test revealing that computer games were indeed beneficial to students.

In addition, Aghlara and Tamjid (2011) report similar findings. In their research, a particular computer game was used to investigate the extent to which computer games can assist students to acquire vocabulary. In particular, they investigated 40 students who were six to seven years of age with no prior knowledge of English. The students were separated into an experimental and a control group consisting of 20 students each. After a 40-day teaching period, during which the experimental group was allowed to practice vocabulary by using computer games, it was found that the students of the experimental group outperformed those of the control group, proving that the use of computer games was more successful in teaching vocabulary to children than other vocabulary practice activities.

Based on the results of the pre-test and the post-test, therefore, it is clear that the effect computer games had on high achievement students was unnoticeable as their performance was already high. For low-achievement students, however, the results were quite astounding. In sheer contrast to their performance in the pre-test, students who were exposed to differentiated instruction and used computer games as a means of practicing vocabulary, managed within a period of 24 weeks to raise their achievement by $38,7 \%$ on average (see Figure 8 ). These findings are in line with a study conducted by Johnson et al. (2004) who investigated the effect computer software had on the communicative competences of students of the Arabic language. In their study, leaners of the experimental group were exposed to vocabulary and expression training in the target language via computers. The results of their study indicated that previous low performance and low confidence learners performed significantly better after practicing on computers.

On the contrary, the performance of the students of the control group, who had to follow the conventional vocabulary teaching method, suggested by the school curriculum for the $4^{\text {th }}$ grade, met with a $2,8 \%$ decrease (see Figure 9) as in the post-test there was only one student of the control group who scored $100 \%$. These findings are in line with the findings of Chuang and Chen (2007) as well as Wu, Lee, Chang and Liang (2013) who studied the effect computer games had on students' cognitive achievement and motivation respectively.

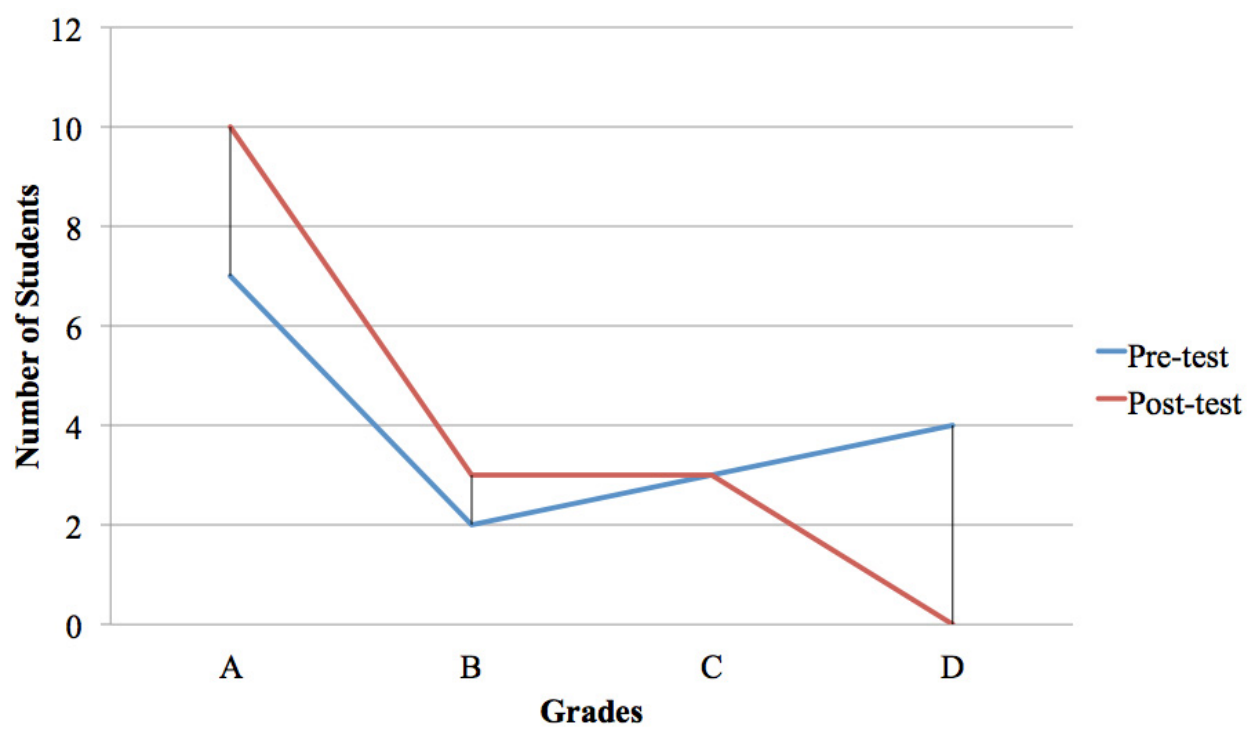

Figure 8. Experimental group pre-test and post-test results

In particular, Chuang and Chen (2007) studied 115 third-graders in Tainan City, China. Students were separated into an experimental and a control group and both a pre-test and a post-test was given to them at the beginning and at the end of the study. Their results indicated that computer games both promoted problem solving skills and aided participants in recalling the processes compared to other traditional methods of practicing vocabulary (such as doing activities in their workbook or learning vocabulary lists). On the other hand, Wu et al. (2013) who investigated the connection between computer games and motivation to learn vocabulary and gain enjoyment from the lesson, concluded that computer games were the key factor in engaging particularly weak learners in 
the English lesson.

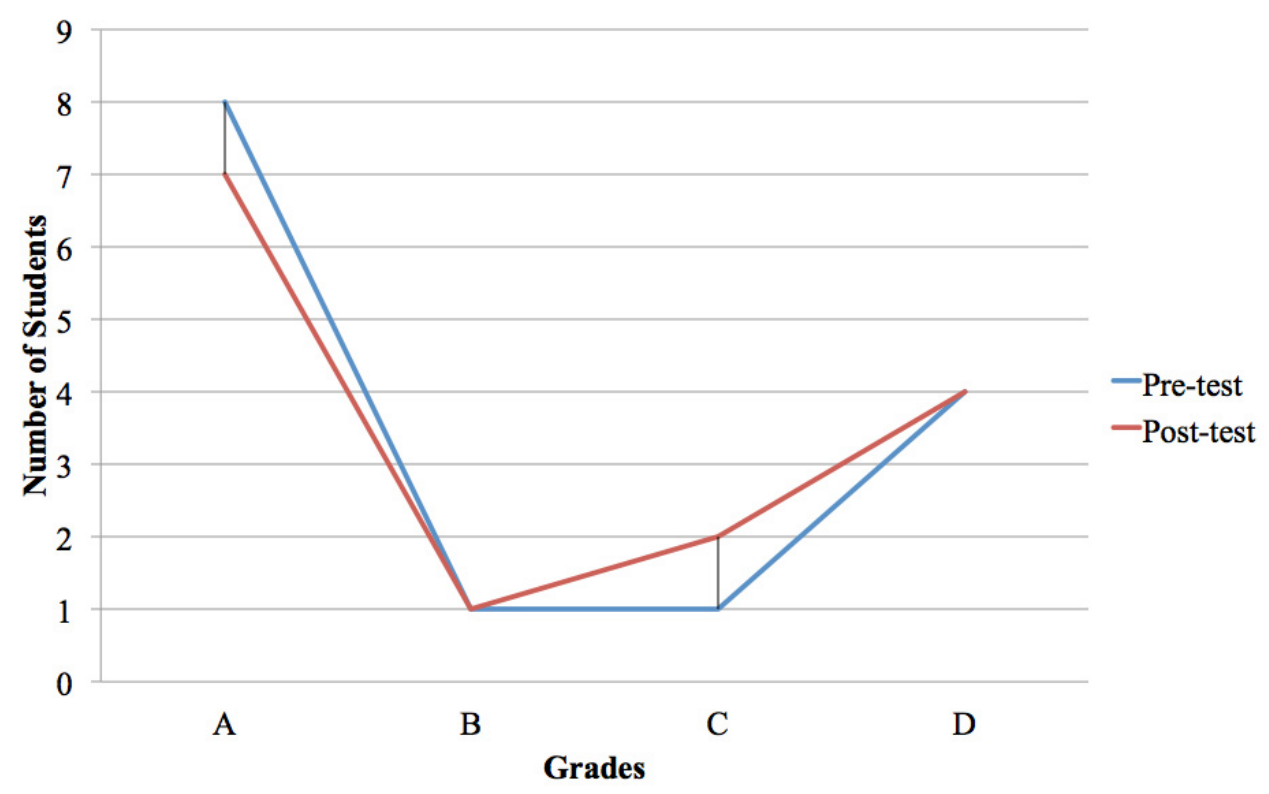

Figure 9. Control group pre-test and post-test results

As a result, based on the aforementioned findings and the findings of this research, it can be suggested that computer games are more beneficial than any other method suggested by the school curriculum not only because they manage to motivate students (Gee, 2007; Wu et al., 2013) but also because they can assist them in retaining the vocabulary they have already learnt more effectively (Chuang \& Chen, 2007; Dominiquez et al., 2013). On the contrary, traditional methods of teaching vocabulary (such as doing Workbook exercises) are often considered boring by learners (Turgut \& Irgin, 2009). As a result, students are unwilling to put much effort in remembering new words which leads to poorer test results (Kulik, 1994).

\subsection{Final Semi-Structured Interview Results}

The final semi-structured interview was conducted only to the students of the experimental group as only they were exposed to differentiated instruction thus their personal opinion on how they viewed the lesson was significant. Students were given the choice of either responding in English or in Greek and, apart from one student who chose to respond in English, all the other students responded in Greek. Before analyzing the axons, which derived from the semi-structured interview responses, it is essential to draw attention to an interesting finding, which derived from the interview and for which the teachers (who were also the researchers) were unaware of; 7 out of 16 students claimed that they used more than one language at home with their parents in addition to Greek. These languages were Russian, Armenian, Pontic and Turkish (see Figure 10), which were the actual mother tongues of the students, thus, making Greek a second language for $43,75 \%$ of the students of the class, which meant that, for those students, English was the third language which they were learning. 


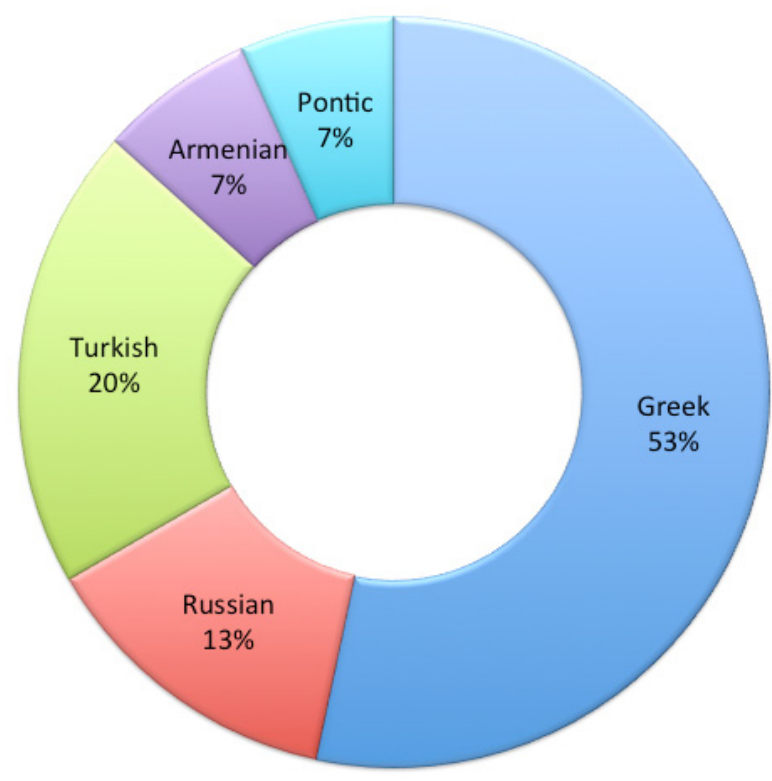

Figure 10. Students' mother tongues

Furthermore, $81.25 \%$ of the students claimed that their level of English needed improvement, while $50 \%$ of the students believed that vocabulary was what needed to be improved (see Figure 11). Another interesting finding, of the semi-structured interview, was that 15 out 16 students replied that they liked learning English while the only student who replied that he did not like English was because of the vocabulary he had to learn. What is more, $59 \%$ of the students, that is 10 out of 16 , claimed that what they found most difficult was learning vocabulary (see Figure 12). These findings are in line with the stance taken by many researchers (Folse, Mitchell, Smith-Palinkas \& Tortorella 2005; Hulstijn, 2011; Read, 2004) who regard vocabulary as the "first and foremost" (Ghanbaran \& Ketabi, 2014) challenge students face when learning a language.

On the other hand, $81.25 \%$ of the students replied that the activities which helped them to learn vocabulary quicker and more effectively, were those which were conducted through the use of online computer games. The effectiveness of learning vocabulary through online computer games is in complete agreement with the study conducted by Calvo-Ferrer (2017), who investigated the effect of computer games in vocabulary acquisition. His results indicated that students of the experimental group, who used computer games to practice vocabulary, reported significantly higher "received learning gains" (Calvo-Ferrer, 2017, p. 264).

The aforementioned findings confirmed the researchers' (who were also the teachers) initial hypothesis that vocabulary was the most significant and the most troublesome aspect of teaching English in the $4^{\text {th }}$ grade as well as the best choice to implement differentiated instruction in this class of students so as to assist them in their effort to learn new words.

As far as the teaching of computer games is concerned, the students' responses were divided into two axons. The first axon reflected the extent to which the students liked working on the computer as a means of learning and revising vocabulary while the second, the extent to which they believed computer games were effective in learning vocabulary. All students unanimously claimed that not only did they like computer games but that they also considered them effective in their effort to improve their English (see Figure 13). These findings are in line with the research conducted by Turgut and Irgin (2008) who investigated the extent to which computer games can be both enjoyable and effective in teaching English vocabulary. Their study was based on the methodological framework of phenomenology and involved 10 primary and secondary school students aged 10-14. The students were observed playing online games and semi-structured interviews were used to investigate both their knowledge of English as well as their opinions regarding computer games. The results indicated that online games not only promoted language learning, especially vocabulary skills, but were also highly motivating and enjoyable for the students. 


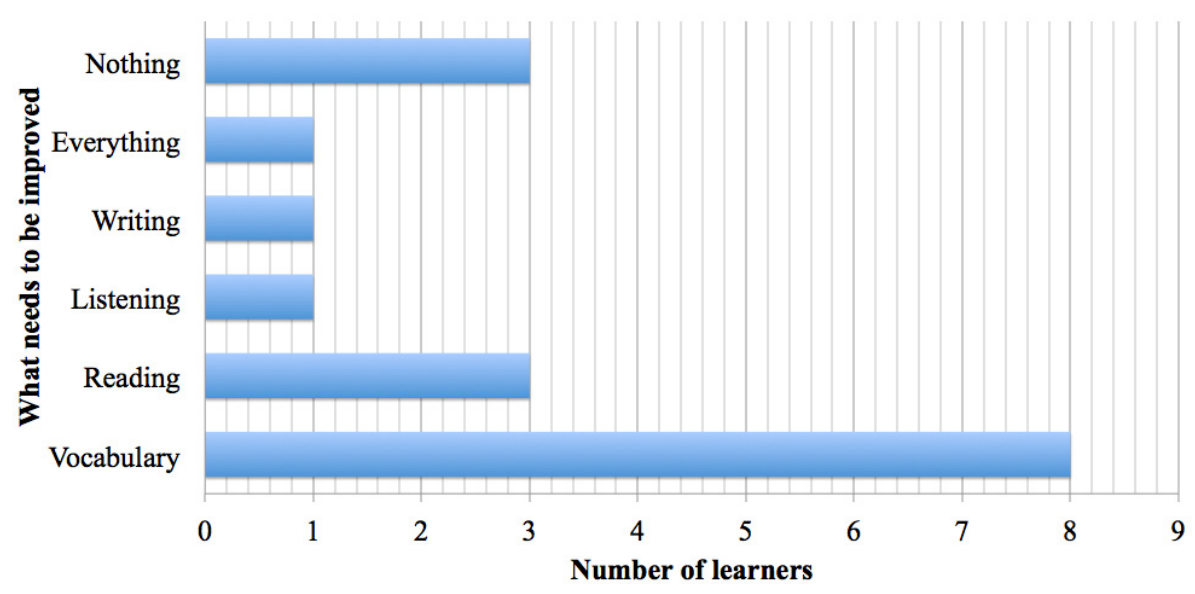

Figure 11. Areas in English that students would like to improve

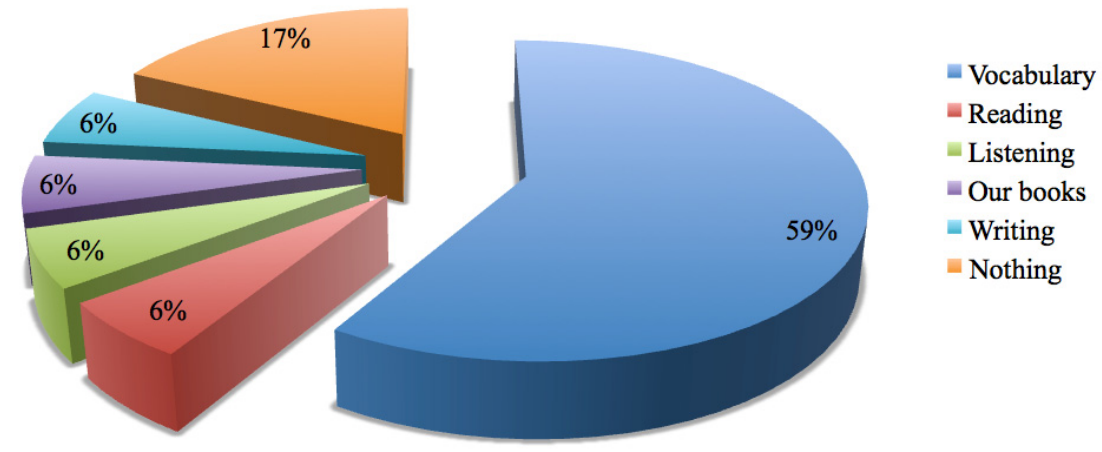

Figure 12. What students find most difficult in learning English

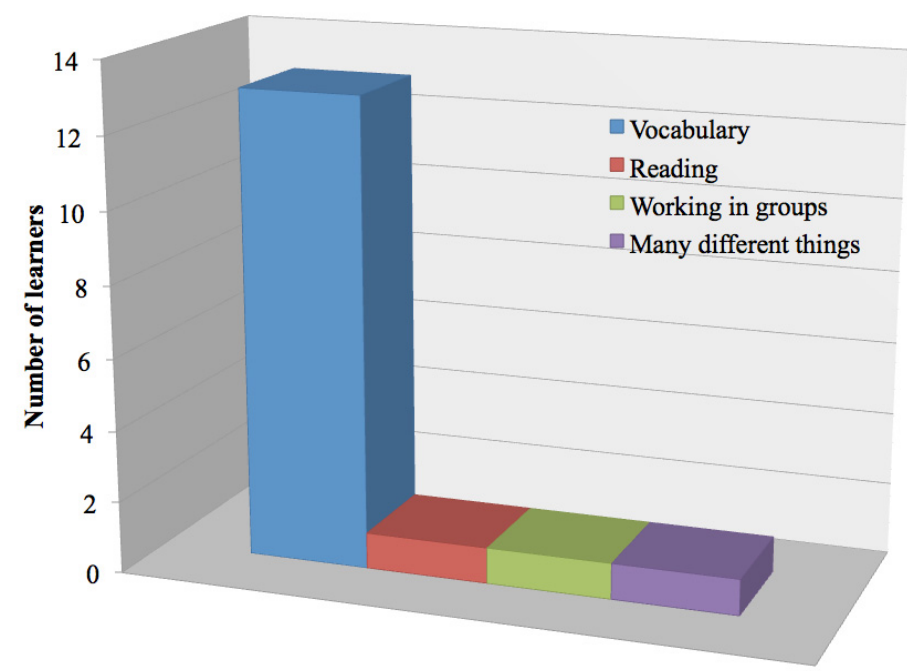

Figure 13. What students believe they improved the most by working on computers

\section{Discussion}

After a meticulous analysis of both the pre-test and the post-test results as well as of the semi-structured interview responses, certain conclusions can be drawn.

First of all, the results confirmed the hypothesis made at the beginning of the research and gave a clear answer to the two research questions posed. Based on the responses that the students of the experimental group provided in the final semi-structured interview and on their performance in the post-test, it was found that computer games 
were both an enjoyable and effective means of teaching vocabulary in English. Furthermore, according to the same results, the implementation of computer games in the lessons instigated positive reactions on the part of the students who believed that by playing computer games they were actually learning English in a way that they truly enjoyed.

A plausible explanation as to why computer games proved to be beneficial especially to low-achievement students is perhaps because they provide a safe environment within which to practice (Gee, 2007). In a computer game, students do not feel that they are exposed to the rest of their classmates and they are more willing to take risks (Gee, 2005), which is regarded as a prerequisite when learning a foreign language (Goodman, 2014). In addition, computer games provide a source of challenge to both high and low achievers, as each game is divided into varying levels of difficulty to suit the ability and knowledge of every player (Hirumi \& Stapleton, 2008). These levels of difficulty are also constantly changing. No matter which level a student starts from, once this level in the game has been completed, the student is challenged once more to win at a higher, more demanding level, thus, keeping his or her interest and motivation intact. This escalation of challenge and of linguistic demands which is placed upon students can be related to Krashen's i+1 Comprehensible Input Hypothesis (Krashen, 1982). According to Krashen (1982), students' progress when learning a language, especially when they are exposed to language which is "slightly above [...] the level of [their] current ability" (Baker \& Jones, 1998, p. 649). In addition, while playing computer games, which by definition are neither dubbed nor subtitled, students are exposed to original spoken English in context, which has proved to benefit their vocabulary skills (Zengin \& Yetkin Aker, 2016). Computer games, therefore, by offering a variety of levels of difficulty, in an original context, and a gradual exposure to new language, manage to offer each student the Comprehensible Input that they need in order to advance linguistically. Students can choose to start playing at the level they can handle and are then gradually exposed to increasingly more difficult vocabulary in increasingly more demanding levels, yet always within the limits of their abilities. This highly individualized practice is something that the regular classroom practice cannot offer to students, particularly to the weaker ones who often have to deal with tasks they have not chosen and which are often more difficult than what they can achieve (Gee, 2003).

Finally, another possible explanation of the findings of this research is the students' use of mnemonics while playing computer games. According to Kahraman and Zengin (2014), students activate various mnemonic strategies when learning foreign language vocabulary and make connections between the target vocabulary and words from their native language both at a phonological and at a semantic level. In vocabulary computer games, therefore, where motivation to retain words in one's memory in order to complete all levels and to win, is high (Khaksari, Mehdijavanmard \& Javanmard, 2014; Olson, 2010; Woo, 2014), students make use of various mnemonic strategies so as to remember the words they are presented with. As a result, their vocabulary skills are enhanced and their vocabulary range is expanded.

\subsection{Educational Implications}

The results of this research show that the educational implications of the application of Online Computer Games, in the ELT Classroom are extensive and far-reaching.

First of all, the results confirm the relevant theory which supports the effectiveness of differentiated instruction (Tomlinson, 2003). The students who were in the $4^{\text {th }}$ grade of the $7^{\text {th }}$ Primary school of Orestiada were given the opportunity to choose the method and the tool which would best help them to learn a particular content in English. Based on the results of this particular research, this freedom of choice had a radical impact on the performance of all students, particularly of the weaker students, and created a feeling of excitement amongst all students, which increased their motivation to learn and to work much harder. This finding suggests that learning English at school can be very interesting, motivating and productive for young students if teachers start the course each year by taking into consideration their students preferences as to how the lesson should take place and what to include in their teaching and by incorporating these preferences in their regular lessons.

In addition, the results of this research confirm the significance of incorporating technology in the English language classroom as it increases students' motivation (Jenks \& Seedhouse, 2015; Levy \& Stockwell, 2013) and also promotes language learning (Chapelle, 2003). The implication of this finding, for the teaching of English in Primary school, is crucial as it suggests that the use of computers should become an inextricable part of the lesson because computers offer enjoyable practice in English as a foreign language.

\section{Limitations of the Research and Suggestions for Further Research}

This research is a small-scale research which included a very small number of students who attended two schools in a rural area of Greece. Its results, therefore, cannot be generalized to account for the rest of the students who are of the same language level in schools across the country, who might have different experiences, likes and 
dislikes and preferred methods of learning English. For the results of this research to be able to be generalized, a large-scale research should be conducted with students of the same language level and age group but of different geographical areas in Greece and its results should be quantitatively analyzed and evaluated. Should the effect computer games have on learning English be found to be significant in the aforementioned research, then, a national plan to systematically integrate computer games in English language teaching at Greek state schools could be forwarded.

\section{Conclusion}

In conclusion, after a meticulous analysis of the data collected during the research, the initial hypothesis that computer games are a motivating and effective means of assisting young learners in improving their English vocabulary has been confirmed by the data. Nevertheless, given the fact that this is a small-scale research, these findings should be treated with caution and should not be overgeneralised. On the other hand, they should be used as a springboard for further, extensive research into the matter so that a clearer picture is formed of the repercussions and influence that computer games can have on the teaching of English to young learners in Greek state schools.

\section{References}

Aglahara, L., \& Tamjid, N. H. (2011). The effect of digital games on Iranian children vocabulary retention in foreign language acquisition. Procedia, Social and Behavioral Sciences, 29, 552-560. https://doi.org/10.1016/j.sbspro.2011.11.275

Ashraf, H., Motlagh, F. G., \& Salami, M. (2014). The impact of online games on learning English vocabulary by Iranian (low-intermediate) EFL learners. Procedia-Social and Behavioural Sciences, 98, 286-291. https://doi.org/10.1016/j.sbspro.2014.03.418

Baker, C., \& Jones, P. S. (1998). An encyclopaedia of bilingual education and bilingualism. Clevedon: Multimedia Matters.

Baker, T. B., \& Milivojevich, A. (2016). Quality by experimental design (4th ed). USA: Taylor \& Francis Group.

Boonkongsaen, N. (2012). Factors affecting vocabulary learning. Naresuan University Journal, 20(2), 45-53.

Bytheway J. (2014). In-game culture affects learners' use of vocabulary learning strategies in massively multiplayer online role-playing games. Int. J. Comput. Assist. Lang. Learn. Teach, 4, 1-13. https://doi.org/10.4018/ijcallt.2014100101

Calvo-Ferrer, J. R. (2017). Educational games as stand alone learning tools and their motivational effects on L2 vocabulary acquisition and perceived learning gains. British Journal of Educational Technology, 48(2), 264-278. https://doi.org/10.1111/bjet.12387

Cameron, L. (2001). Teaching languages to young students. Cambridge: Cambridge University Press. https://doi.org/10.1017/CBO9780511733109

Chambers, G. N. (1999). Motivating language students. Great Britain: Multilingual Matters LTD.

Chapelle, C. A. (2003). Language learning \& teaching: English language learning and technology. Amsterdam/Philadelphia: John Benjamins Publishing Company. https://doi.org/10.1075/1llt.7

Chuang, T., Y., \& Chen, W. F. (2007). Digital games for cognitive learning: A pilot study. Journal of Scientific and Technological Studies, 41(1), 17-27.

Coady, J., \& Huckin T. (1997). Second language vocabulary acquisition. New York: Cambridge University Press.

Dominguez, A., Saenz-de-Navarrete, J., de-Marcos, L., Fernandez-Sanz, L., Pages, C., \& Martinez-Herraiz, J.J. (2013). Gamifying learning experiences: Practical implications and outcomes. ELSEVIER Computers \& Education, 63, 380-392. https://doi.org/10.1016/j.compedu.2012.12.020

Ellis, R. (1994). The study of second language acquisition. China: Oxford University Press.

Folse, K. S., Mitchell, D., Smith-Palinkas, B., \& Tortorella, D. M. (2005). Clear grammar: Activities for spoken and written communication. Michigan: University of Michigan Press. https://doi.org/10.3998/mpub.91591

Frost, P. (2002). Principles of the action research cycle. In R. Ritchie, R. A. Pollard, P. Frost, \& T. Eaude (Eds.), Action research: A guide for teachers. Burning issues in primary education (3rd ed., pp. 24-32). Birmingham: National Primary Trust.

Gee, J. P. (2003). What video games have to teach us about learning and literacy. New York: Palgrave/ 
Macmillan.

Gee, J. P. (2005). Why video games are good for your soul: Pleasure and learning. Melbourne: Common Ground.

Gee, J. P. (2007). Good video games + Good leaning: Collected essays on video games, learning and literacy. USA: University of Michigan. https://doi.org/10.3726/978-1-4539-1162-4

Ghanbaran, S., \& Ketabi, S. (2014). Multimedia games and vocabulary learning. Theory and Practice in Language Studies, 4(3), 489-496. https://doi.org/10.4304/tpls.4.3.489-496

Goodman, K. S. (2014). Revaluing readers and reading. In K. S. Goodman, \& Y. M. Goodman (Eds.), Making sense of learners making sense of written language: The selected articles of Kenneth S. Goodman and Yetta M. Goodman (pp. 189-196). New York: Routledge.

Hirumi, A., \& Stapleton, C. (2008). Applying pedagogy during game development to enhance game-based learning. In C. T. Miller (Ed.), Games: Purpose and potential in education (pp. 127-162). USA: Springer.

Hopkins, D. (2002). A teacher's guide to action research (3rd ed.). Buckingham: Open University Press.

Hulstijn, J. H. (2003). Incidental and intentional learning. In C. J. Doughty, \& M. H. Long (Eds.), The handbook of second language acquisition (pp. 349-536). UK: Blackwell Publishing. https://doi.org/10.1002/9780470756492.ch12

Jenks, C., \& Seedhouse, P. (2015). International perspectives on ELT classroom interaction. India: MPS Limited. https://doi.org/10.1057/9781137340733

Jensen, S. H. (2017). Gaming as an English language learning resource among young children in Denmark. CALICO Journal; San Marcos, 31(1), 1-19. http://doi.org/10.1558/cj.29519

Johnson, W. L., Beal, C., Fowles-Winkler, A., Lauper, U., Marsella, S., Narayanan, \& Vilhjálmsson, H. (2004). Tactical language training system: An interim report. In J. C. Lester (Ed.), Intelligent tutoring system: Lecture notes in computer science (Vol. 3220, pp. 336-345). Berlin: Springer Heidelberg. https://doi.org/10.1007/978-3-540-30139-4_32

Kahraman, C. \& Zengin, B. (2014). Facilitation potential of the mnemonics for the teaching of Japanese vocabulary to Turkish speaker. Humanitas, International Journal of Social Sciences, 2(4), 165-182. https://doi.org/10.20304/husbd.51154

Khaksari, Z., Mehdijavanmard, Javadyarahmadi (2014). Computer games and psychological motivation in adolescents. Advances in Natural and Applied Sciences, 8(10), 119-125.

Krashen, S. D. (1982). Principles and practices in second language acquisition. Oxford: Pergamon.

Krashen, S. D. (1989). We acquire vocabulary and spelling by reading: Additional evidence for the Input Hypothesis. The Modern Language Journal, https://doi.org/10.1111/j.1540-4781.1989.tb05325.x

Kulik, J. A. (1994). Meta-analytic studies of findings on computer-based instruction. In E. L. Baker, \& F, O’N. \& Jr, Harold (Eds.), Technology assessment in education training, (Vol. 1, pp. 9-34). Hillsdale, NJ: Lawrence Erlbaum Associates, Inc..

Laufer, B. (1990). Why are some word more difficult to learn than others? Some intralexical factors that affect the learning of words. International Review of Applied Linguistics in Language Teaching, 28(4), 293-308. https://doi.org/10.1515/iral.1990.28.4.293

Laufer, B. (1997). What's in a word that makes it hard or easy? Some intralexical factors that affect learning of words. In N. Schmitt, \& M. McCarthy (Eds.), Vocabulary: Description, acquisition and pedagogy (pp. 140-155). UK: Cambridge University Press.

Letchumanan, K., \& Bee Hoon, T. (2012). Using computer games to improve secondary school students' vocabulary acquisition in English. Social Sciences and Humanities, 20(4), 1005-1018.

Levy, M., \& Stockwell, G. (2013). CALL dimensions: Options and issues in computer assisted language learning. ESL \& applied linguistics professional series. Mahwah, NJ: Routledge.

MacLeod, S. (2007). Experimental design. Simply Psychology. Retrieved from http://www.simplypsychology.or g/experimental-designs.html

McCarthy, M. J. (1990). Vocabulary. Oxford: Oxford University Press. 
Meara, P. (1980). Vocabulary acquisition: A neglected aspect of language learning. Language Teaching and Linguistics: Abstracts, 13, 221-246.

Moorhead, C. (2006). Experimental designs. Dartmouth College Assessment Camp. Retrieved from https: $/ /$ www.google.gr/search?client=safari\&rls=en\&q=www.dartmouth.edu\&ie=UTF8\&oe=UTF8\&gfe_rd=cr\&e

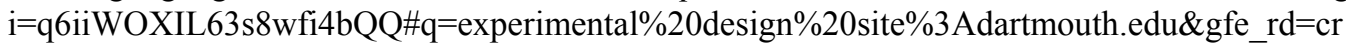

Mpratsoli, A., \& Diamantidou, A. (2009). English for the $4^{\text {th }}$ grade. Teacher's book. Athens: School Book Publishing Organisation (OEDB).

Mpratsioli, A., \& Diamantidou, A. (2011a). English for the $4^{\text {th }}$ grade: Activity Book. Athens: School Book Publishing Organisation (OEDB).

Mpratsioli, A., \& Diamantidou, A. (2011b). English for the $4^{\text {th }}$ grade. Student's book. (3rd ed.) Athens: School Book Publishing Organisation (OEDB).

Olson, C. K. (2010). Children's Motivations for video game play in the context of normal development. Review of general Psychology, 14(2), 180-187. http://doi.org/10.1037/a0018984

Osguthorpe, R. T., \& Osguthorpe, L. S. (2009). Choose to learn. Teaching for success every day. USA: Corwin Press.

Prensky, M. (2001). Digital natives, digital immigrants. On the Horizon, 9(5), 1-6. https://doi.org/10.1108/10748120110424843

Read, J. (2004). Research in teaching vocabulary. Annual Review of Applied Linguistics, Cambridge University Press, 24, 146-161. https://doi.org/10.1017/S0267190504000078

Reason, P., \& Bradbury, H. (2006). Action research. Great Britain: Sage Publications. https://doi.org/10.1177/1476750306063988

Ringboom, H. (1985). On L1 transfer in L2 comprehension and L2 production. Language Learning: A Journal of Research in Language Studies, 42(1), 85-112. https://doi.org/10.1111/j.1467-1770.1992.tb00701.x

Ross, B. M., \& Jan, A. (2007). How to teach students to be fluent writers: Grades 3-5 (2nd ed.). USA: Teacher Created Resources.

Saffanian, R., \& Gorjian, B. (2012). Effect of computer-based video games for vocabulary acquisition among young children: An experimental study. Journal of Comparative Literature and Culture, 1(3), 44-48.

Savage, J. (2010). Cross-curricular teaching and learning in the secondary school. USA and Canada: Routledge.

Savage, J. (2011). Cross-curricular teaching and learning in the primary school. Oxon: Routledge.

Segers, E., \& Verhoeven, L. (2003). Effects of vocabulary training by computer on kindergarten. Journal of Computer Assisted Learning, 19, 557-566. https://doi.org/10.1046/j.0266-4909.2003.00058.x

Sundqvist, P., \& Sylvèn, L. K. (2014). Language-related computer use: Focus on young L2 English learners in Sweden. ReCALL, 26, 3-20. https://doi.org/10.1017/S0958344013000232

Swan, M. (1997). The influence of mother tongue on second language vocabulary acquisition and use. In N. Schmitt, \& M. McCarthy (Eds.), Vocabulary: Description, acquisition and pedagogy (pp. 156-180). UK: Cambridge University Press.

Swanborn, P. G. (2010). Case study research: What, why and how? India: Sage.

Takac, V. P. (2008). Vocabulary learning strategies and foreign language acquisition. Great Britain: Multilingual Matters.

Tomlison, C. A. (2001). How to differentiate instruction in mixed-ability classrooms (2nd ed.) Alexandria, Virginia, USA: ASCD.

Tomlinson, C. A. (2003). Fulfilling the promise of the differentiated classroom: Strategies and tools for responsive teaching. Alexandria, VA: Association of Supervision and Curriculum Development.

Turgut, Y., \& Irgin, P. (2009). Young learners' language learning via computer games. Procedia, Social and Behavioral Sciences, 1, 760-764. https://doi.org/10.1016/j.sbspro.2009.01.135

Vermeer, A. (1992). Exploring the second language learner lexicon. In L. Verhoeven, \& J. H. A. L. De Jong (Eds.), The construct of language proficiency (pp. 147-162). Philadelphia, USA: John Benjamin's Publishing Company. https://doi.org/10.1075/z.62.16ver 
Woo, J. (2014). Digital game-based learning supports student motivation, cognitive success and performance outcomes. Journal of Education technology \& Society, 17(3), 291-307.

Wu, H. K., Lee, S. W. Y., Chang, H. Y., \& Liang, J. C. (2013). Current status, opportunities and challenges of augmented reality in education. ELSEVIER Computers \& Education, 62, 41-49. https://doi.org/10.1016/j.compedu.2012.10.024

Yip, F. W. M., \& Kwan, A. C. M. (2006). Online vocabulary games as a tool for teaching and learning English vocabulary. Educational Media International, 43(3), 233-249. https://doi.org/10.1080/09523980600641445

Yudintseva, A. (2015). Game-enhanced second language vocabulary acquisition strategies: A systematic review. Open Journal of Social Sciences, 3, 101-109. https://doi.org/10.4236/jss.2015.310015

Zengin, B., \& Yetkin Aker, D. (2016). Education policy and the effect of subtitle options in learning process: A case of Turkish students as English language learners. Humanitas, A Journal of Social Sciences, 4(7), 485-498. https://doi.org/10.20304/husbd.88126

\section{Copyrights}

Copyright for this article is retained by the author(s), with first publication rights granted to the journal.

This is an open-access article distributed under the terms and conditions of the Creative Commons Attribution license (http://creativecommons.org/licenses/by/4.0/). 